\title{
Compost-Containing Substrates and Their Effect on Posttransplant Growth of Containerized Tree Seedlings
}

\author{
Bruce R. Roberts
}

\begin{abstract}
Greenhouse studies were undertaken to determine the influence of composted media on the posttransplant growth of containerized red maple, sugar maple, and green ash seedlings. Before planting, the chemical and physical properties of each substrate were measured. For media containing composted biosolids, $\mathrm{pH}$ was significantly higher, whereas electrical conductivity, air-filled porosity, and total pore space were significantly lower than in a composted medium without biosolids. For composted substrates containing at least some soil, bulk density, particle density, and container capacity were all significantly greater than for composts without any soil. Growth of red maple was about the same in a noncomposted soilless medium (Metro-mix 360) as it was in substrates containing biosolid compost. Height growth, total biomass, and root biomass of green ash were all significantly greater for seedlings grown in Metro-mix 360 only, and the growth of sugar maple seedlings was about the same in Metro-mix 360 or in a composted substrate without biosolids (Metro-mix 560). The results of this study suggest no particular short-term growth advantage of using composted media as backfill amendments when transplanting; however, the addition of composts could be beneficial in improving the chemical and physical properties of native soils, particularly urban soils containing very low levels of organic matter.
\end{abstract}

Key Words. Acer rubrum L.; Acer saccharum Marsh.; biosolids; Fraxinus pennsylvanica Marsh; soil amendments; soil properties; tree establishment.

There are conflicting reports regarding the potential benefits derived from incorporating soil amendments into the backfill of transplanted trees and shrubs. Schulte and Whitcomb (1975) reported seeing no benefit from using amendments in the backfill soil of silver maple, Acer saccharinum L., and Corley (1984) found no consistent, positive growth responses when several difficult-to-establish landscape trees and shrubs were transplanted in traditional backfill amendments. In studies with 1-year-old red maple (Acer rubrum L.) and Washington hawthorne [Crataegus phaenopyrum (L.f.) Medic.] seedlings, Kelting et al. (1998) reported that native backfill soil amended with yard waste compost at planting had no appreciable effect on height, stem diameter, or root length of either species, although shoot biomass of hawthorne was greater when seedlings were grown in composted yard waste than in native backfill only. Gilman (2004) reported that during the first and second year after transplanting into good soil, there was no apparent benefit from adding composted yard waste to the backfill soil around newly planted $5 \mathrm{~cm}$ (2 in) caliper live oaks (Quercus virginiana Mill.), and Ferrini et al. (2005) found that plant growth (shoot growth and leaf area) of 5-year-old balled-and-burlapped English oak (Quercus robur L.) was only rarely better when transplanted in excavated soil amended with $50 \%$ yard waste versus growth in excavated soil only.
Contrary to these findings, Gouin and Walker (1977) found that stem length in yellow poplar (Liriodendron tulipifera $\mathrm{L}$.) and dogwood (Cornus florida L.) was greater when seedlings of both species were grown in screened compost containing digested sewage sludge and wood chips. Similarly, Banko (1984) found that the growth index of transplanted willow (Salix matsudana 'Tortuosa') was significantly greater at the end of the second growing season for plants grown in compost-incorporated planting beds. Hodge (1995) also reported improved tree survival of English oak seedlings 3 years after transplanting in clay soils amended with manure and sewage sludge, and Smalley and Wood (1995) found that balled-andburlapped clonal Acer rubrum trees (3 cm [1.2 in] caliper) exhibited greater fibrous root growth in a proprietary product composed of, among other things, composted poultry litter.

Although controversy remains about the usefulness of adding organic amendments to backfill soils during planting, there is general agreement among arborists that many urban tree planting sites often lack adequate organic matter content, nutrient availability, and water-holding capacity to ensure the likelihood of establishment. Under such conditions, the addition of organic amendments might prove beneficial in improving soil $\mathrm{pH}$, increasing overall biologic activity, promoting better drainage and enhancing nutrient-holding capacity. Also, the addition of compost may improve physical charac- 
teristics by promoting better soil structure and lowering penetration resistance to root growth as reported by Ferrini et al. (2005).

Composts, defined here as products resulting from the controlled biologic decomposition of organic wastes, are proving to be potentially beneficial to plant growth when used as soil amendments (Tyler 1996). Because the availability of newly marketed, economic, organically amended waste products is constantly changing, and because composted waste products have been used successfully to grow a wide variety of horticultural crops, including fruit trees (Autio et al. 1991), woody shrubs (Beeson and Keller, 2001), bedding plants (Klock-Moore 1999), vegetables (OzoresHampton et al. 2005), wildflowers (Roberts et al. 2001a), and turf (Roberts et al. 2001b), the present investigation was undertaken to further study the effects of compost-containing substrates, especially those containing municipal solid waste (MSW), on the survival and establishment of woody seedlings.

These studies were conducted in a greenhouse to help eliminate some of the environmental variables associated with field trials, other than planting medium composition, that might confound the results. Seedling material was used as a first step before testing on a larger scale using transplanted trees in the urban landscape.

\section{METHODS}

A series of compost-containing media were obtained from commercial sources in the spring of 2003. Media used in this investigation included: Com-Til (CT), an MSW product from the city of Columbus, Ohio, U.S., composted with wood chips and screened to $1 \mathrm{~cm}$ (0.4 in); Garden Plus Topsoil (GPT), a mixture of $40 \%$ pulverized soil, $30 \% \mathrm{CT}$, and $30 \%$ flume sand (Earthco, Inc., Columbus, Ohio); Soil Plus (SP), a mixture of $60 \%$ soil, $20 \% \mathrm{CT}$, and $20 \%$ concrete sand (Jones Topsoil \& Mulch, Columbus, Ohio); Container Mix (CM), a combination of biosolid compost, organic forest compost, rice hulls, pine bark, and silica sand (Kurtz Bros., Cleveland, Ohio); and Metro-mix 560 (MM560), a mixture of composted pine bark, coconut coir pith, sphagnum peat moss, processed bark ash, and perlite (Sun Gro Horticulture, Vancouver, BC, Canada). Metro-mix 360 (MM360), a noncomposted soilless substrate consisting of horticultural vermiculite, sphagnum peat moss, processed bark ash, and washed sand (Sun Gro Horticulture), was used as the control medium in these investigations.

Chemical and physical properties were determined for each medium. Chemical properties ( $\mathrm{pH}$ and electrical conductivity) were measured using three replicated samples containing equal parts substrate and deionized water $(1: 1[\mathrm{v} / \mathrm{v}])$. To determine physical properties, the technique of Niedziela and Nelson (1992) was used to measure bulk density, particle density, air-filled porosity, and container capacity of three replicated water:substrate samples $(2: 1[\mathrm{v} / \mathrm{v}])$ of each medium. Percent pore space was calculated from bulk density and particle density measurements using the relationship described by Brady and Weil (1999).

In the first series of experiments (part 1), acceleratedgrowth Jiffy Plug ${ }^{\circledR}$ seedlings (5 cm [2 in] diameter plug size) of red maple (Acer rubrum L.) and green ash (Fraxinus pennsylvanica Marsh.) were obtained from a commercial nursery and transplanted into $3.8 \mathrm{~L}$ (1 gal) plastic pots containing various combinations of CT and MM360. Jiffy Plug seedlings (seedlings in which the root system is growing in a peat pellet encased in biodegradable mesh) were used in this part of the study to simulate the conditions that exist when planting balled-and-burlapped rather than bare-root plant material. Environmental conditions in the partially shaded greenhouse during the January through March experimental period ranged from $18^{\circ} \mathrm{C}$ to $26^{\circ} \mathrm{C}\left(64^{\circ} \mathrm{F}\right.$ to $\left.79^{\circ} \mathrm{F}\right), 60 \pm 12 \%$ relative humidity, and 80 to $120 \mathrm{~W} / \mathrm{m}^{2}$ photosynthetically active radiation (PAR) (natural day length plus supplemental illumination from $175-\mathrm{W}$ metal halide lamps on a $2 \mathrm{hr}$ photoperiod [0600 to $0800 \mathrm{hr}$ ]).

In the second set of experiments (part 2), 2-year-old bareroot seedlings of red and sugar maple (Acer saccharum Marsh.) were obtained from a commercial nursery and planted in $3.8 \mathrm{~L}$ (1 gal) plastic pots containing either compost-amended soils (GPT; SP), soilless compost-containing media (CM; MM560), or noncomposted soilless substrate (MM360). Environmental conditions in the greenhouse for these investigations, which ran from June through August, ranged from $19^{\circ} \mathrm{C}$ to $30^{\circ} \mathrm{C}\left(66^{\circ} \mathrm{F}\right.$ to $\left.86^{\circ} \mathrm{F}\right), 65 \pm 15 \%$ relative humidity, and 90 to $120 \mathrm{~W} / \mathrm{m}^{2}$ PAR. No supplemental illumination was used in part 2 .

Seedlings in both studies were hand-watered as needed and fertilized biweekly with a water-soluble, all-purpose fertilizer containing $21 \mathrm{~N}-2.2 \mathrm{P}-16.6 \mathrm{~K}$ and supplemented with $10 \%$ chelated iron, $0.02 \%$ boron, $0.01 \%$ copper, $0.05 \%$ manganese, $0.01 \%$ molybdenum, and $0.07 \%$ zinc. Weekly height measurements were recorded for each seedling and, approximately 12 weeks later, measurements of leaf area, leaf, stem, and root biomass were determined after harvesting the seedlings, washing off the root systems, and oven-drying the tissue from each sample at $90^{\circ} \mathrm{C}\left(194^{\circ} \mathrm{F}\right)$ for $48 \mathrm{hr}$. Height growth measurements were expressed as percent increase in height and, to standardize variance, were converted to arcsin transformations before statistical analyses. The experimental design used in both studies was a completely randomized block with either five (part 1) or six (part 2) single-plant replications per treatment. For each species, differences in seedling growth were analyzed using the least significant difference (LSD) method for pairwise comparisons at a probability level of $0.05 \%$ (Analytical Software 2003). 


\section{RESULTS AND DISCUSSION \\ Chemical Properties of Media}

An important chemical property of any soil or growing medium is its $\mathrm{pH}$, a factor that influences the availability of essential mineral nutrients. The $\mathrm{pH}$ of $\mathrm{CT}$ and CT-containing substrates in these studies was consistently and significantly higher than it was for composted media without CT (Table 1). Although the $\mathrm{pH}$ of media containing mixtures of CT and MM360 averaged 7.3, the pH of CT-amended soils (GPT and SP) and soilless composts (CM and MM560) averaged 6.6 and 5.2, respectively. Although the $\mathrm{pH}$ of $\mathrm{CT}$ was approximately neutral (7.4), it should be noted that the hydrogen ion concentration of this product (like with other MSW-containing products) may vary considerably from batch to batch, depending on the biosolid content and length of the composting process. In certain instances, it may be necessary to leach some MSW-containing products with water to bring the $\mathrm{pH}$ within a more acceptable range for planting.

Although plants can be grown in solution culture over a wide $\mathrm{pH}$ range (assuming precautions are taken to keep the essential elements in solution), in nature, $\mathrm{pH}$ is more critical because it affects the solubility of essential mineral elements. In higher $\mathrm{pH}$ (alkaline) media, iron and phosphorus deficiencies can sometimes become a problem, whereas in lower $\mathrm{pH}$ (acidic) media, calcium and magnesium are frequently deficient (Kramer and Kozlowski 1979). In the current study, most of the media tested were within a $\mathrm{pH}$ range expected to yield adequate nutrients for plant growth; however, MM560, at $\mathrm{pH} 4.8$, could affect nutrient availability if large quantities of this product were used exclusively as a backfill amendment.
Conductivity measurements in this study ranged from $<1$ to $>14 \mathrm{dS} / \mathrm{m}$ (Table 1). As a general rule, EC values of saturated soil/media extracts greater than $4 \mathrm{dS} / \mathrm{m}$ are considered high (Lal and Shukla 2004) and thus may not support good growth for some plant species. According to these guidelines, 3 of the media tested in this study (GPT, SP, and MM560) may need to be leached with water to reduce potentially high salt buildup. However, the ion content contributed by the addition of a relatively small amount of compost would normally be overwhelmed by the ion content of a proportionately larger volume of backfill soil.

The MSW component of many composts can contain heavy metals that could be phytotoxic (Chaney 1973). An independent laboratory analysis of the CT used in these studies by the Ohio Cooperative Extension Service revealed the following heavy metal content $(\mathrm{ppm})$ : cadmium $=14$; chromium $=176$; copper $=249 ;$ lead $=209 ;$ nickel $=66$; and zinc $=1531$. In the United States, federal regulations regarding the use of sewage sludge have recently been adopted under section 503 of the Clean Water Act, but there are no federal laws or regulations that apply specifically to solid waste composting (Harrison and Richard 2005). Although there are many similarities between sewage sludges and MSW-derived composts, there are also important differences (e.g., bioavailability of metals, ratio between different metals). However, considering the 'risk-based' approach for regulating compost quality, the heavy metal content of CT used in these studies was within recommended guidelines.

\section{Physical Properties of Media}

Sustainable use of a soil or other planting medium cannot be achieved unless the physical conditions of the medium are

Table 1. Chemical and physical properties of media used to grow containerized tree seedlings ${ }^{2}$.

\begin{tabular}{|c|c|c|c|c|c|c|c|}
\hline \multirow[b]{2}{*}{ Media $^{y}$} & \multicolumn{2}{|c|}{ Chemical properties ${ }^{\mathrm{x}}$} & \multicolumn{5}{|c|}{ Physical properties $^{\mathrm{w}}$} \\
\hline & $\mathrm{pH}$ & $\mathrm{EC}(\mathrm{dS} / \mathrm{m})$ & $\mathrm{BD}\left(\mathrm{g} / \mathrm{cm}^{3}\right)$ & $\mathrm{PD}\left(\mathrm{g} / \mathrm{cm}^{3}\right)$ & $\operatorname{AFP}(\%)$ & $\mathrm{CC}(\%)$ & PS (\%) \\
\hline $\mathrm{CT}$ & $7.4 \mathrm{a}$ & $3.6 \mathrm{~d}$ & $0.3 \mathrm{c}$ & $0.5 \mathrm{~d}$ & $8.7 \mathrm{e}$ & $66.9 \mathrm{c}$ & $46.7 \mathrm{e}$ \\
\hline 3CT:1MM & $7.5 \mathrm{a}$ & $2.4 \mathrm{e}$ & $0.3 \mathrm{c}$ & $0.7 \mathrm{c}$ & $7.2 \mathrm{f}$ & $77.1 \mathrm{~b}$ & $54.2 \mathrm{cde}$ \\
\hline 1CT:1MM & $7.4 \mathrm{a}$ & $2.1 \mathrm{ef}$ & $0.2 \mathrm{~d}$ & $0.5 \mathrm{~d}$ & $5.4 \mathrm{~g}$ & $73.1 \mathrm{~b}$ & $60.0 \mathrm{bcc}$ \\
\hline 1CT:3MM & $7.1 \mathrm{ab}$ & $1.3 \mathrm{fg}$ & $0.1 \mathrm{e}$ & $0.3 \mathrm{e}$ & $3.2 \mathrm{~h}$ & $67.4 \mathrm{c}$ & $61.1 \mathrm{bc}$ \\
\hline $\mathrm{CM}$ & $5.6 \mathrm{~d}$ & $4.5 \mathrm{~d}$ & $0.2 \mathrm{~d}$ & $0.5 \mathrm{~d}$ & $20.9 \mathrm{~b}$ & $60.7 \mathrm{~d}$ & $60.0 \mathrm{bcc}$ \\
\hline MM560 & $4.8 \mathrm{e}$ & $14.3 \mathrm{a}$ & $0.1 \mathrm{e}$ & $0.5 \mathrm{~d}$ & $22.7 \mathrm{a}$ & $61.7 \mathrm{~d}$ & $78.3 \mathrm{a}$ \\
\hline
\end{tabular}

${ }^{\mathrm{z}}$ Values represent the mean of three replications. Values in the same column differ significantly when followed by a different letter, $\mathrm{LSD}_{0.05}$.

${ }^{\mathrm{y}}$ Refer to text for description of media composition.

${ }^{\mathrm{x}}$ Each sample consisted of a water:substrate ratio of 1:1 (v/v). EC = electrical conductivity; $\mathrm{pH}$ and EC of water used in sample preparation $=5.91$ and 0.02 , respectively.

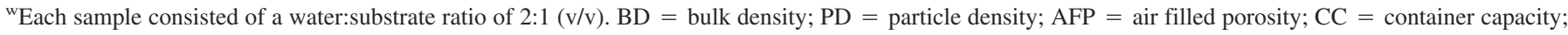
$\mathrm{PS}=$ pore space. 
maintained at a satisfactory level (Lal and Shukla 2004). The addition of fertilizer alone will not likely preserve productivity of a planting substrate if physical conditions are not maintained above some minimum threshold level or if significant deterioration of physical quality occurs.

Bulk density, sometimes referred to as apparent density, is the ratio of oven-dried soil or medium per unit volume (Gerrard 2000). Thus, a dense medium has more solids per unit volume than a porous medium. As expected, bulk density values for the soil-containing composts used in the current study (GPT and SP) were significantly higher than the bulk densities of those media without any soil (Table 1). Similarly, for substrates containing a biosolid component, bulk density averaged $\approx 0.4 \mathrm{~g} / \mathrm{cm}^{3}$, whereas for substrates without any biosolids, bulk density was significantly lower $\left(0.1 \mathrm{~g} / \mathrm{cm}^{3}\right)$. Bulk density values for soils acceptable for plant growth range from 0.7 to $1.8 \mathrm{~g} / \mathrm{cm}^{3}$ (Lal and Shukla 2004), but for media containing organic compost, bulk density would likely be lower.

Particle density is defined as the mass per unit volume of soil particles (Brady and Weil 1999). The particle densities of inorganic soils normally range from 2.6 to $2.8 \mathrm{~g} / \mathrm{cm}^{3}$, whereas those for organic matter are usually about half that amount (Lal and Shukla 2004). The particle densities of media used in the current study varied from $1.6 \mathrm{~g} / \mathrm{cm}^{3}$ for $S P$ to $0.3 \mathrm{~g} / \mathrm{cm}^{3}$ for MM360 and 1CT:3MM (Table 1), all of which are lower than expected for unamended backfill soils. Like with bulk density, the particle density of compost-amended soils (GPT and SP) was always significantly higher than for media without soil. As expected, the higher the amount of organic matter in the medium, the lower the particle density.

Air-filled porosity (AFP) is a measure of the relative proportion of air-filled pores in a soil or planting substrate. In relation to plant growth, media with AFP values of $7 \%$ or lower are most likely to have problems of poor drainage (Bragg and Chambers 1988). However, plants can be grown successfully in low AFP media provided that water management is carefully controlled. In the current study, AFP values for MM360 and substrates containing MM360 were significantly lower then those for media without MM360 (Table 1). For MM360 alone and for mixtures of MM360 and CT, porosity measurements were sometimes below the $7 \%$ threshold level, suggesting that anaerobiosis could be a concern.

Container capacity represents the total per cent water, by volume, held by a saturated soil or planting substrate in the absence of evapotranspiration. Almost any soil, amended or nonamended, when placed in a container will retain a larger volume of available water than will the same soil under field conditions (White and Mastalerz 1966). Thus, the use of containers changes the normal physical relationship between roots and substrate for plants growing under such conditions (Bunt 1961). This is an important consideration not only for container-grown plant material in greenhouse studies such as reported here, but also for planting pits and above-ground containers in which growing space can be severely restricted. In the current study, container capacities were greatest in composted substrates containing soil (GPT, SP) and significantly lower for soilless substrates, especially those without any CT (MM360, MM560, CM) (Table 1).

Pore space is an expression of the volume of pores to the total volume of soil or planting medium and is usually determined from the relationship between bulk density and particle density (Gerrard 2000). For soils or planting media with the same particle density, the lower the bulk density, the higher the percent pore space. A medium-textured, well-granulated soil or planting medium in good condition for plant growth would have pore space of $\approx 50 \%$ (Brady and Weil, 1999). However, porosity can range from as low as $25 \%$ in compacted soils/media to more than $60 \%$ in well-aggregated, high organic matter content soils/media. The pore space of media used in the present investigation ranged from $46.7 \%$ for CT to $78.3 \%$ for MM560 (Table 1). For compost-amended soils (GPT and SP), porosity was $51 \%$, a pore space considered "ideal" for plant growth. For composted media containing biosolids, with or without soil, percent pore space was always significantly lower than it was for a composted medium without any biosolids (MM560). With the possible exception of MM560, all media tested in this study were considered to have porosity values expected to support good root growth.

\section{Part 1: Growth of Jiffy Plug Seedlings in MSW Compost (CT) and Noncomposted (MM360) Substrates}

For Jiffy Plug red maple seedlings (simulated balled-andburlapped plant material), total biomass was significantly greater in substrates containing only noncomposted media (MM360) than in substrates containing only MSW compost (CT) (Table 2). For substrates containing mixtures of CT and MM360, overall growth was significantly better in a medium with greater quantities of MM360 (1CT:3MM) than in a medium with greater quantities of CT (3CT:1MM). In fact, maple seedlings planted in 3CT:1MM never really became established as evidenced by the absence of new shoot growth, lower total plant biomass, and a significantly higher root: shoot ratio (Table 2). Shoot (stem and leaf) dry weight of seedlings grown in noncomposted substrate only (MM360) was always significantly greater than for comparable seedlings grown in MSW compost only (CT) (Table 2); and leaf, stem, and root dry weights were consistently higher for seedlings in substrates containing more noncomposted substrate (MM360 only; 1CT:3MM).

In one of the few backfill amendment studies involving balled-and-burlapped Acer rubrum, Smalley and Wood (1995) reported no significant difference in either root or shoot growth of red maple trees $(3 \mathrm{~cm}$ [1.2 in] caliper) planted in $60 \mathrm{~cm}(24 \mathrm{in})$ diameter by $30 \mathrm{~cm}$ (12 in) deep 
Table 2. Growth of containerized Jiffy Plug red maple (Acer rubrum L.) and green ash (Fraxinus pennsylvanica Marsh.) seedlings in composted MSW media and in a noncomposted substratez.

\begin{tabular}{|c|c|c|c|c|c|c|c|c|}
\hline \multirow[b]{2}{*}{ Species } & \multirow[b]{2}{*}{ Media $^{y}$} & \multirow{2}{*}{$\begin{array}{l}\text { Height } \\
\text { growth }(\%)\end{array}$} & \multicolumn{4}{|c|}{ Biomass (g) } & \multirow[b]{2}{*}{$\mathrm{R} / \mathrm{S}$} & \multirow{2}{*}{$\begin{array}{l}\text { Leaf area } \\
\left(\mathrm{cm}^{2}\right)\end{array}$} \\
\hline & & & Leaf & Stem & Root & Total & & \\
\hline \multirow[t]{5}{*}{ Red maple } & $\mathrm{CT}$ & $1.0 \mathrm{ab}$ & $0.63 \mathrm{bc}$ & $4.24 \mathrm{~b}$ & $4.83^{\mathrm{ns}}$ & $9.70 \mathrm{bc}$ & $1.09 \mathrm{ab}$ & $22.4 \mathrm{bc}$ \\
\hline & MM360 (MM) & $4.9 \mathrm{ab}$ & $3.23 \mathrm{a}$ & $5.63 \mathrm{a}$ & 5.50 & $14.36 \mathrm{a}$ & $0.65 \mathrm{c}$ & $113.6 \mathrm{ab}$ \\
\hline & 3CT:1MM & $0.0 \mathrm{~b}$ & $0.0 \mathrm{c}$ & $4.28 \mathrm{ab}$ & 5.17 & $9.41 \mathrm{c}$ & $1.21 \mathrm{a}$ & $0.0 \mathrm{c}$ \\
\hline & 1CT:1MM & $3.6 \mathrm{ab}$ & $0.54 \mathrm{bc}$ & $4.54 \mathrm{ab}$ & 4.74 & $9.82 \mathrm{bc}$ & $1.01 \mathrm{ab}$ & $6.0 \mathrm{c}$ \\
\hline & 1CT:3MM & $7.4 \mathrm{a}$ & $2.33 \mathrm{ab}$ & $5.14 \mathrm{ab}$ & 5.67 & $13.13 \mathrm{ab}$ & $0.85 \mathrm{bc}$ & $136.8 \mathrm{a}$ \\
\hline \multirow[t]{5}{*}{ Green ash } & $\mathrm{CT}$ & $2.6 \mathrm{bc}$ & $1.83 \mathrm{c}$ & $4.22 \mathrm{c}$ & $4.45 \mathrm{c}$ & $10.50 \mathrm{c}$ & $0.80^{\mathrm{ns}}$ & $41.3 \mathrm{c}$ \\
\hline & MM360 (MM) & $27.9 \mathrm{a}$ & $6.06 \mathrm{a}$ & $6.88 \mathrm{a}$ & $10.54 \mathrm{a}$ & $23.42 \mathrm{a}$ & 0.82 & $434.7 \mathrm{a}$ \\
\hline & 3CT:1MM & $3.9 \mathrm{bc}$ & $3.02 \mathrm{bc}$ & $4.48 \mathrm{c}$ & $4.96 \mathrm{c}$ & $12.46 \mathrm{c}$ & 0.73 & $142.8 \mathrm{bc}$ \\
\hline & 1CT:1MM & $13.1 \mathrm{~b}$ & $4.45 \mathrm{ab}$ & $5.87 \mathrm{~b}$ & $7.42 \mathrm{~b}$ & $17.48 \mathrm{~b}$ & 0.76 & $288.1 \mathrm{ab}$ \\
\hline & 1CT:3MM & $0.0 \mathrm{c}$ & $2.57 \mathrm{bc}$ & $4.73 \mathrm{c}$ & $5.58 \mathrm{c}$ & $12.86 \mathrm{c}$ & 0.82 & $85.5 \mathrm{c}$ \\
\hline
\end{tabular}

${ }^{\mathrm{z}}$ Seedlings grown for 12 weeks (January to March) in 1 gal plastic containers in the greenhouse (80 to $120 \mathrm{~W} / \mathrm{m}^{2}$ photosynthetically active radiation [natural daylight + supplemental illumination from 175-W metal halide lamps on a $2 \mathrm{hr}$ photoperiod 0600 to $0800 \mathrm{hr}]$ ). Each value represents the mean of six replications. To standardize the variance, height growth percentages were converted to arcsin transformations before statistical analyses. Within each species, values in the same column differ significantly when followed by a different letter, $\mathrm{LSD}_{0.05}$; ns $=$ not significant.

${ }^{\mathrm{y}}$ Refer to text for description of media composition.

planting holes backfilled with a proprietary product containing composted poultry litter. The current study, although involving plant material considerably smaller in size, also suggests that red maples planted in backfill amendments containing appreciable quantities of solid waste compost (CT in this instance) may not grow as well as similar maples planted in backfill soils amended with a noncomposted substrate such as MM360.

For Jiffy Plug green ash seedlings, growth (percent height increase and total biomass) was significantly better when seedlings were planted in MM360, a noncompost-containing substrate (Table 2). Leaf, stem, and root biomass were also consistently greater for seedlings grown in the noncomposted substrate; however, no significant differences in root:shoot ratio were observed between any of the treatments. In mixtures of CT and MM360, green ash grew best in a medium containing equal parts of both substrates (1CT:1MM). These results are different from those observed for red maple, in which seedlings grew best in a mixture containing more MM360 (1CT:3MM). One possible explanation may be the difference in physical properties between the two media. Bulk density, particle density, air-filled porosity, and container capacity of 1CT:1MM were all significantly higher than for 1CT:3MM (Table 1). Because the growth rate of green ash normally exceeds that of red maple (Nowak et al. 2002), one might expect a faster-growing species to outperform a moderately growing one, especially in short-term studies such as those reported here.

Watson et al. (1992) have reported that root density (after 1 year) and terminal growth and trunk diameter (after 2 years) of Fraxinus pennsylvanica 'Summit' trees (5 to $7 \mathrm{~cm}$ [2 to 2.8 in] in diameter) were not significantly different when planted in unamended backfill soil, in soil amended with sand and composted organic matter, or in friable topsoil. The authors concluded that although there is no reason not to use amended backfill soils when transplanting trees of this size, there may be no significant benefit in terms of increased growth. In the current study, the only appreciable growth advantage noted for transplanted green ash seedlings was when a noncomposted substrate (MM360) was used exclusively as the growing medium. Under these circumstances, height growth, total biomass, and leaf area were all significantly greater than for most of the remaining treatments (Table 2).

\section{Part 2: Growth of Bare-Root Seedlings in Biosolid Compost (GPT; SP; CM), in Compost Without Biosolids (MM560) and in Noncomposted Substrate (MM360)}

There seemed to be no particular advantage in growing bareroot red maple seedlings in any of the composted media, with or without biosolids, versus growing them in a noncomposted substrate (Table 3). Within the compost treatments used in this investigation, seedlings grown in media containing biosolids (GPT, SP, CM) generally grew better than seedlings planted in a medium without biosolids (MM560), but only occasional significant differences were noted. The root:shoot ratio of compost-grown maples was generally higher than for maples planted in a noncomposted medium (Table 3), suggesting that root growth might be stimulated to a greater degree than shoot growth in these treatments; however, the variability between replicates was so great that no definite conclusions could be drawn from these data.

In a study of posttransplant growth of 1-year-old, bare-root red maple seedlings, Kelting et al. (1998) reported that a 
Table 3. Growth of 2-year-old bare-root containerized red maple (Acer rubrum L.) and sugar maple (Acer saccharum Marsh.) seedlings in composted and noncomposted substrates ${ }^{z}$.

\begin{tabular}{|c|c|c|c|c|c|c|c|c|}
\hline \multirow[b]{2}{*}{ Species } & \multirow[b]{2}{*}{ Media $^{\mathrm{y}}$} & \multirow{2}{*}{$\begin{array}{l}\text { Height } \\
\text { growth }(\%)\end{array}$} & \multicolumn{4}{|c|}{ Biomass (g) } & \multirow[b]{2}{*}{$\mathrm{R} / \mathrm{S}$} & \multirow{2}{*}{$\begin{array}{l}\text { Leaf area } \\
\left(\mathrm{cm}^{2}\right)\end{array}$} \\
\hline & & & Leaf & Stem & Root & Total & & \\
\hline \multirow[t]{5}{*}{ Red maple } & GPT & $12.2 \mathrm{a}$ & $0.85 \mathrm{ab}$ & $2.06 \mathrm{ab}$ & $3.58 \mathrm{ab}$ & $6.48 \mathrm{ab}$ & $1.39 \mathrm{a}$ & $145.5 \mathrm{ab}$ \\
\hline & SP & $9.0 \mathrm{ab}$ & $0.47 \mathrm{~b}$ & $1.17 \mathrm{~b}$ & $2.01 \mathrm{bc}$ & $3.65 \mathrm{~b}$ & $1.30 \mathrm{ab}$ & 77.6 b \\
\hline & $\mathrm{CM}$ & $4.6 \mathrm{ab}$ & $1.52 \mathrm{a}$ & $2.65 \mathrm{a}$ & $4.39 \mathrm{a}$ & $8.56 \mathrm{a}$ & $1.00 \mathrm{~cd}$ & $300.0 \mathrm{a}$ \\
\hline & MM560 & $3.0 \mathrm{~b}$ & $0.26 \mathrm{~b}$ & $1.15 \mathrm{~b}$ & $1.47 \mathrm{c}$ & $2.88 \mathrm{~b}$ & $1.07 \mathrm{bc}$ & $43.7 \mathrm{~b}$ \\
\hline & MM360 & $5.6 \mathrm{ab}$ & $1.56 \mathrm{a}$ & $2.23 a b$ & $2.71 \mathrm{abc}$ & $6.49 \mathrm{ab}$ & $0.73 \mathrm{~d}$ & $299.2 \mathrm{a}$ \\
\hline \multirow[t]{5}{*}{ Sugar maple } & GPT & $3.2 \mathrm{~b}$ & $0.08 \mathrm{~b}$ & $1.13^{\mathrm{ns}}$ & $1.74^{\mathrm{ns}}$ & $2.95^{\mathrm{ns}}$ & $1.98^{\mathrm{ns}}$ & $17.5 \mathrm{ab}$ \\
\hline & SP & $0.6 \mathrm{~b}$ & $0.33 \mathrm{ab}$ & 0.80 & 1.96 & 3.18 & 1.98 & $59.4 \mathrm{a}$ \\
\hline & $\mathrm{CM}$ & $0.6 \mathrm{~b}$ & $0.02 \mathrm{~b}$ & 1.20 & 1.44 & 2.65 & 1.23 & $3.6 \mathrm{~b}$ \\
\hline & MM560 & $23.2 \mathrm{a}$ & $0.60 \mathrm{ab}$ & 0.52 & 1.53 & 2.65 & 1.34 & $108.5 \mathrm{a}$ \\
\hline & MM360 & $9.8 \mathrm{ab}$ & $0.64 \mathrm{a}$ & 0.89 & 2.17 & 3.70 & 1.86 & $100.2 \mathrm{a}$ \\
\hline
\end{tabular}

${ }^{\mathrm{z}}$ Seedlings grown for 12 weeks (June to August) in 1 gal plastic containers in the greenhouse under natural daylight. Each value represents the mean of five replications. To standardize the variance, height growth percentages were converted to arcsin transformations before statistical analyses. Within each species, values in the same column differ significantly when followed by a different letter, $\mathrm{LSD}_{0.05}$; $\mathrm{ns}=$ not significant.

${ }^{\mathrm{y}}$ Refer to text for description of media composition.

treatment consisting of three parts native backfill soil to one part yard waste compost (by volume) did not increase height, stem diameter, top dry weight, or root length after 2 years when compared with a treatment of native backfill soil only. In the current study, the compost treatment most closely approximating that used by Kelting et al. was the SP treatment (60\% soil:20\% compost:20\% sand). As already noted, red maple seedlings grown in SP did not show any significant increase in height growth when compared with the other media tested, and there were no significant differences in any of the growth parameters measured between SP and the other soil-containing substrate (GPT) used in these studies (Table 3).

For bare-root Acer saccharum, height growth of seedlings in MM560, a soilless compost without any biosolids, was significantly greater than it was in any of the other compostcontaining media (GPT, SP, or CM) used in this study (Table 3). Although total biomass of MM560-grown seedlings was not significantly different than it was for any of the other treatments, leaf area was significantly greater than for at least one other compost-containing substrate (CM), and leaf dry weight for maples grown in MM560 was appreciably greater than it was in the other media tested, except for the control.

Although no studies could be found in the literature dealing specifically with the effects of soil amendments on posttransplant growth of sugar maple, investigators working with other Acer species have reported a variety of responses. Schulte and Whitcomb (1975) found no particular benefit when silver maples (Acer saccharinum L.) were planted in backfill soil amended with bark and peat moss and, as already mentioned, Kelting et al. (1998) found no increase in the growth of bare-root Acer rubrum seedlings planted in native backfill soil amended with composted yard waste. On the other hand, Smalley and Wood (1995) reported increased fibrous root growth in balled-and-burlapped red maples 2 years after planting in backfill amended with topsoil, pine humus, granite sand, crushed granite, expanded shale, and composted poultry litter. The results with 2 -year-old bare-root sugar maple seedlings in the current study suggest that there was no particular advantage when seedlings of this species were grown in a variety of compost-containing media for 12 weeks.

Acknowledgments. This project was carried out with financial support from the TREE Fund's John Duling research grant program. The author acknowledges statistical advice provided by Bert L. Bishop, Ohio Agricultural Research and

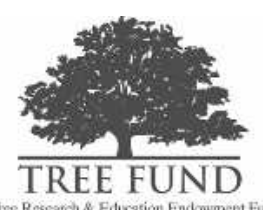

Development Center, Wooster, Ohio.

\section{LITERATURE CITED}

Analytical Software. 2003. Statistix 8 User's Manual. Tallahassee, FL. 396 pp.

Autio, W.R., D.W. Greene, D.R. Cooley, and J.R. Schupp. 1991. Improving the growth of newly planted apple trees. HortScience 26:840-843.

Banko, T.J. 1984. Composted sewage sludge as a soil amendment for landscape trees and shrubs. Proceedings of the SNA Research Conference 29:113-117.

Beeson, R.C. Jr., and K.G. Keller. 2001. Yard waste compost as a landscape soil amendment for azaleas. Journal of Environmental Horticulture 19:222-225.

Brady, N.C., and R.R. Weil. 1999. The Nature and Properties of Soils, 12th edition. Prentice-Hall, Inc., Upper Saddle River, NJ. 881 pp.

Bragg, N.C., and B.J. Chambers. 1988. Interpretation and advisory applications of compost air-filled porosity (AFP) measurements. Acta Horticulturae 221:35-44. 
Bunt, A.C. 1961. Some physical properties of pot plant composts and their effect on plant growth: 1. Bulky physical conditions. Plant and Soil 13:322-323.

Chaney, R.L. 1973. Crop and food chain effects on toxic elements in sludges and effluents, pp. 129-146. In Compost: Production, Quality and Use. DeBertoldi, M., Ferranti, M.P., Hermite, L., and Zucconi F., Eds. Elsevier Applied Science, New York, NY.

Corley, W.L. 1984. Soil amendments at planting. Journal of Environmental Horticulture 2:27-30.

Ferrini, F., A. Giuntoli, F.P. Nicese, S. Pellegrini, and N. Vignozzi. 2005. Effect of fertilization and backfill amendments on soil characteristics, growth and leaf gas exchange of English oak (Quercus robur L.). Journal of Arboriculture 31:182-189.

Gerrard, J. 2000. Fundamentals of Soils. Routledge, New York, NY. 230 pp.

Gilman, E.F. 2004. Effects of amendments, soil additives, and irrigation on tree survival and growth. Journal of Arboriculture 30:301-304.

Gouin, F.R., and J.M. Walker. 1977. Deciduous tree seedling response to nursery soil amended with composted sewage sludge. HortScience 12:45-47.

Harrison, E.Z., and T.R. Richard. 2005. Municipal solid waste composting: Issues in policy and regulation. MSW Composting Fact Sheet No. 6, Cornell University, Ithaca, NY. 5 pp.

Hodge, S.J. 1995. The effect of seven organic amendments on planting pit soil and tree performance. Arboricultural Journal 19:245-266.

Kelting, M., J.R. Harris, J. Fanelli, and B. Appleton. 1998. Biostimulants and soil amendments affect two-year posttransplant growth of red maple and Washington hawthorne. HortScience 33:819-822.

Klock-Moore, K.A. 1999. Growth of impatiens 'Accent Orange' in two compost products. Compost Science \& Utilization 7:58-62.

Kramer, P.J., and T.T. Kozlowski. 1979. Physiology of Woody Plants. Academic Press, Inc., New York, NY. 811 pp.

Lal, R., and M.J. Shukla. 2004. Principles of Soil Physics. Marcel Dekker, Inc., New York, NY. 716 pp.

Niedziela, C.E. Jr., and P.V. Nelson. 1992. A rapid method for determining physical properties of undisturbed substrate. HortScience 27:1279-1280.

Nowak, D.J., J.C. Stevens, S.M. Sisinni, and C.J. Luley. 2002. Effects of urban tree management and species selection on atmospheric carbon dioxide. Journal of Arboriculture 28:113-122.

Ozores-Hampton, M., P.A. Stansly, R. McSorley, and T.A. Obreza. 2005. Effects of long-term organic amendments and soil solarization on pepper and watermelon growth, yield, and fertility. HortScience 40:80-84.
Roberts, B.R., H.F. Decker, K.J. Bagstad, and K.A. Peterson. 2001a. Biosolid residues as soilless media for growing wildflower sod. HortTechnology 11:194-199.

Roberts, B.R., H.F. Decker, L.M. Ganahl, and E. Yarmark. 2001b. Biosolid residues as soilless media for growing creeping bentgrass sod. HortTechnology 11:451-455.

Schulte, J.R., and C.E. Whitcomb. 1975. Effects of soil amendments and fertilizer levels on the establishment of silver maple. Journal of Arboriculture 1:192-195.

Smalley, T.J., and C.B. Wood. 1995. Effect of backfill amendment on growth of red maple. Journal of Arboriculture 21:247-249.

Tyler, R.W. 1996. Winning the Organics Game. The Compost Marketer's Handbook. American Society of Horticultural Science Press, Alexandria, VA. 269 pp.

Watson, G.W., G. Kupkowski, and K.G. von der HeideSpravka. 1992. The effect of backfill soil texture and planting hole shape on root regeneration of transplanted green ash. Journal of Arboriculture 18:130-134.

White, J.W., and J.W. Mastalerz. 1966. Soil moisture as related to 'container capacity.' Proceedings of the American Society for Horticultural Science 89:758-765.

\author{
Bruce R. Roberts \\ Department of Botany and Microbiology \\ Ohio Wesleyan University \\ Delaware, OH 43015, U.S. \\ broberts@owu.edu
}

Résumé. Des études en serre ont été menées afin de déterminer l'influence du substrat composté sur la croissance posttransplantation de semis d'érable rouge, d'érable à sucre et de frêne de Pennsylvanie en contenant. Préalablement à la plantation, les propriétés chimiques et physiques de chaque substrat ont été mesurées. Pour le substrat contenant des bio-solides, le $\mathrm{pH}$ était significativement plus élevé tandis que la conductivité électrique, la porosité à l'air et la quantité totale d'espace des pores étaient plus faibles, et ce par rapport au substrat sans bio-solides. Pour les substrats compostés contenant au moins un peu de sol, la densité du sol, la densité en particules et la capacité des contenants étaient tous significativement plus grandes que pour les composts sans sol. La croissance de l'érable rouge était à peu près la même dans un substrat non composté sans sol (Metro-mix 360) que dans les substrats contenant des bio-solides compostés. La croissance en hauteur, la biomasse totale et la biomasse racinaire du frêne de Pennsylvanie étaient significativement plus grandes pour les semis dans le Metromix 360 seul, et la croissance des semis d'érable à sucre était la même dans le Metro-mix 360 que dans un substrat composté sans bio-solides (Metro mix 560). Les résultats de cette étude suggèrent qu'il n'y a pas d'avantage particulier à court terme sur la croissance à employer un substrat composté comme amendement au matériel de remplissage lors de la transplantation; néanmoins, l'ajout de compost peut être bénéfique pour améliorer les propriétés chimiques et 
physiques du sol du sol naturel, particulièrement dans les sols urbains contenant de faibles niveaux de matière organique.

Zusammenfassung. Es wurden Gewächshausstudien unternommen, um den Einfluss von Kompost auf das Wachstum nach der Verpflanzung von getopften Rotahornen, Zuckerahornen und Eschensämlingen zu bestimmen. Vor der Pflanzung wurden die chemischen und physikalischen Eigenschaften jedes Substrates gemessen. Bei Substraten mit kompostierten biologischen Feststoffen war der $\mathrm{pH}$-Wert wesentlich höher, während die elektrische Leitfähigkeit, das Porenvolumen und totale Porenraum niedriger war als in einem Substrat ohne biologische Feststoffe. Kompostmaterialien mit geringen Bodenanteilen hatten mehr Körperdichte, Partikeldichte und Containerkapazität als Komposte ohne Bodenanteil. Das Wachstum von Rotahorn war in einem Nichtkompostierten bodenlosen Medium (Metro-mix 360) etwa so groß wie in einem Substrat mit biologischen Feststoffen. Das Höhenwachstum, totale Biomasse und Wurzelbiomasse bei der Esche war bei Sämlingen in Metro-mix 360 am größten und bei Zuckerahorn war das Wachstum in Metromix 360 oder in kompostiertem Substrat ohne Feststoffe (Metro-mix 560) etwa gleich. Die Ergebnisse dieser Studie zeigen keinen besonderen Vorteil bei der Verwendung von Kompostmaterial. Dennoch könnte der Zusatz von Kompost sich positiv auf die chemischen und physikalischen Eigenschaften von natürlichen Böden auswirken, besonders bei Stadtböden mit einem geringen organischen Anteil.
Resumen. Se llevaron a cabo estudios para determinar la influencia del medio composteado en el crecimiento postransplante de brinzales containerizados de maple rojo, maple azucarero y fresno verde. Antes de la plantación, se midieron las propiedades químicas y físicas de cada sustrato. Para los compuestos con biosólidos, el pH fue significativamente mayor mientras que la conductividad eléctrica, porosidad con aire y espacio total de poros fueron significativamente más bajos que en otro compuesto sin biosólidos. Para los sustratos de composta de al menos algún suelo, la densidad aparente, la densidad de partículas, y la capacidad del contendor fueron significativamente mayores que para los compuestos sin cualquier suelo. El crecimiento del maple rojo fue más o menos el mismo en un medio no composteado sin suelo (Metro-mix 360) como lo fue en un sustrato conteniendo compuesto biosólido. El crecimiento en altura, biomasa total y biomasa de raíz del fresno verde fueron todos significativamente mayores para los brinzales creciendo en Metromix 360 solamente, y el crecimiento de maple azucarero fue más o menos el mismo en Metro-mix 360 o en un sustrato composteado sin biosólidos (Metro-mix 560). Los resultados de este estudio no sugieren una ventaja en crecimiento a corto plazo usando medio composteado como mejorador del relleno cuando se hace el trasplante; sin embargo, la adición del compuesto podría ser benéfica para mejorar las propiedades químicas y físicas de los suelos nativos, particularmente en suelos urbanos que contienen bajos niveles de materia orgánica. 